\title{
Research on the Teaching Reform of Power Enterprise Management
}

\section{Curriculum}

\author{
Yan Tao Wang \\ School of Economics and Management, Northeast Dianli University, Jilin 132012, China \\ wangyantao@gmail.com
}

Keywords: Power enterprise management; Teaching reform; Curriculum orientation; Teaching method; Textbook analysis

\begin{abstract}
Power enterprise management curriculum is one of the common courses for electrical engineering, economics and management specialty in electric power university. This paper makes a full consideration on the actual conditions of the current reform on power management system and the need to establish a modern enterprise management institution. Because of the macro environment of the electricity power industry is changing constantly, power enterprises management curriculum teaching reform need to be done frequently. Based on the notion of individualized education, this paper is trying to explore the reform plan of power enterprises management curriculum teaching with regard to its subject character. By studying and putting into practice the course orientation and aim, course system and contents, this paper comes up with a systematic reform plan for power enterprises management curriculum.
\end{abstract}

\section{Introduction}

Since the reform in power system has deeply developed, the electrical power industry has a new macro environment. Power enterprise takes a great change on system, operation mode and management forms. The whole power line seeks administrative staff full of professional ability on business management. Thus, the course of power enterprise management should make some corresponding adjustment on its teaching level, content and method and so on ${ }^{[1-3]}$. The teaching study on this course should made in order to satisfy the demands of teaching, meet the social requires for power talents ${ }^{[4,5]}$.

\section{Curriculum Orientation and Characteristics}

Curriculum Orientation. Power enterprise management curriculum is a permanent course for electrical engineering specialty and economics and management specialty in university. Professional courses in institutions of higher learning are set according to the national teaching plan and the development prospects of the industry. Electric power industry belongs to the energy sector and is absolutely necessary, thus, power companies have higher market level and good economic benefit and students in this profession have better employment prospect. If an university has electrical engineering academy it is convenient and benefit to set power enterprise management for economics and management institute so that students in this academy have chance to find job in power industry ${ }^{[6-11]}$.

Curriculum Characteristics. In electrical engineering institute the major courses are electric power system and its automation, power electronics and power transmission, high voltage and 
insulation technology, new energy technology and application of electronic and motion control, etc. Many teachers and students think that the course of power enterprise management has less value. Thus the course is set from compulsory course to optional course.

While the major curriculum in school of economics and management are organizational behavior, economic mathematics, accounting, human resource management, company management, marketing and so on. Thus, the course of power enterprise management also is set as an optional one.

Being necessary and subordinate the power enterprise management has become an awkward course. To improve the status of this course is conforming to the need of the society. Most undergraduate majoring in electrical engineering will work in power plants and electric power bureau and most of them will engage in the management work. Thus, it is necessary for students in this profession to have some knowledge about power industry management. If the students from school of economics and management have the chance to work in power companies it is more necessary to know electric power and take the course of power enterprise management. The course should be set as a compulsory one or given more class hour.

\section{Textbook Analysis}

Books of the power enterprise management have mainly three patterns on contents. The first one is to introduce enterprise management and its basic theories and then introduce the knowledge combining with the characteristics of the electric power enterprise. For example, the previous chapters are respectively set as produce and development of the modern enterprise, enterprise system, organization system, production, marketing, sales and other basic business management theory. And the subsequent chapters are respectively given the contents of the general situation, production, sales, dispatch, and financial management in power enterprise and so on. The second pattern gives less knowledge on general enterprise management and more on production and operation management in power line. The whole chapters are power enterprise introduction, power market, power production, power decision, etc. the third kind takes a component of company's management as a key, such as decision problem, the whole chapters are decision-making function of power enterprise, power enterprise strategic decision and business decision.

It is visible some of the books of power enterprise management are suitable for leadership and some of them are fit for students in university. Some of the books focus on power knowledge and others give both stress on enterprise management and power enterprise management. The choice of book is mainly decided by the users. As a textbook for students the first pattern is more rational. While the teaching hour of each chapter should be arranged differently if the students are not only from electrical engineering specialty but also from economics and management specialty. The hour arrangement is shown in table 1 .

In addition, to solve thoroughly the selection difficulty of the textbook, especially the university which set the class of power enterprise in more than two academies should take this course as education reform object and organize some relevant professional teachers to write special textbook for its own school.

Table 1 Teaching time arrangement for different specialty

\begin{tabular}{|c|c|c|c|}
\hline \multirow{2}{*}{ Chapters } & \multicolumn{2}{|c|}{$\begin{array}{c}\text { Teaching Time Arrangement } \\
\text { (Hours) }\end{array}$} \\
\cline { 3 - 4 } & \multirow{2}{*}{ Contents } & $\begin{array}{c}\text { Electrical } \\
\text { Engineering } \\
\text { Specialty }\end{array}$ & $\begin{array}{c}\text { Economics and } \\
\text { Management } \\
\text { Specialty }\end{array}$ \\
\hline
\end{tabular}




\begin{tabular}{|c|c|c|c|}
\hline \multirow{3}{*}{$\begin{array}{ll}\text { Introduction } & \text { on } \\
\text { enterprise } & \\
\text { management } & \end{array}$} & Modern enterprise management & 4 & 0 \\
\hline & General situation of power plant & 0 & 4 \\
\hline & $\begin{array}{lll}\begin{array}{l}\text { Overview of power enterprise } \\
\text { management }\end{array} & & \\
\end{array}$ & 2 & 2 \\
\hline \multirow[t]{3}{*}{ Power production } & Production management & 4 & 0 \\
\hline & Power production & 0 & 4 \\
\hline & Management on power production & 6 & 8 \\
\hline \multirow{3}{*}{$\begin{array}{l}\text { Power industry } \\
\text { market }\end{array}$} & Market overview & 4 & 0 \\
\hline & Operating model of power market & 2 & 4 \\
\hline & Sales of power & 4 & 6 \\
\hline \multirow{3}{*}{$\begin{array}{l}\text { Strategic } \\
\text { decision-making } \\
\text { of power } \\
\text { enterprise }\end{array}$} & Decision-making theory & 4 & 0 \\
\hline & $\begin{array}{l}\text { Decision-making environment of power } \\
\text { industry }\end{array}$ & 2 & 4 \\
\hline & $\begin{array}{l}\text { Develop decision-making of power } \\
\text { industry }\end{array}$ & 4 & 4 \\
\hline \multirow{2}{*}{$\begin{array}{l}\text { Enterprise } \\
\text { informatization }\end{array}$} & Informatization management & 2 & 0 \\
\hline & Power enterprise informatization & 2 & 2 \\
\hline \multirow{2}{*}{$\begin{array}{l}\text { Human, financial } \\
\text { and material } \\
\text { management }\end{array}$} & $\begin{array}{l}\text { Management theory on human, finance } \\
\text { and materials }\end{array}$ & 4 & 0 \\
\hline & $\begin{array}{l}\text { Human, financial and material } \\
\text { management of power enterprise }\end{array}$ & 4 & 10 \\
\hline \multicolumn{2}{|r|}{ Total hours } & 48 & 48 \\
\hline
\end{tabular}

\section{Teaching Research}

Problems of Course Contents. Our country is in the process of the reform of electric power industry system. The structure of power industry has adjusted repeatedly and the enterprise environment is constantly changing. The object and means of management in power line has updated in recent years. However in the actual teaching process, the class contents of power enterprise management are too old. Teaching materials still are the introduction on the beginning of the power reform and less on the new development of the industry. There are few universities or colleges which put the hotspots of the power reform into lessons. The topics of reform are, for example, renovation in rural power grid, three intensive objects and five big systems (intensive management on human, finance and materials, big program, big construction, big operation, big overhaul and big marketing systems). The bad effect is that the students learn the old knowledge about power development and unable to find job better.

There are several main reasons. First, the textbook is wrong or the update of which can't keep up with the development. Second, the teaching hours are too short for teachers to tell basic theories and new line developing needs both. Third, the methods of teaching are boring and single and cannot stimulate students' discussion.

Update of Course Contents. Course contents should reflect the development of the times and the need of modern enterprises. It is necessary to discuss that whether the arrangement of teaching contents can break the inherent mode. In traditional teaching the teachers tell much on basic theories about power enterprise management and arrange only several hours to tell hotspots or need of the power industry. This arrangement is not good for students to master the skills solving management problem which is the target of teaching. Power enterprise management is a course of 
practical characteristic. The teaching contents should change and increase the lessons to tell the new development of the power industry and the chapters of the textbook should change or add new contents as the table below.

Table 2 Contents renovation of power enterprise management curriculum

\begin{tabular}{|l|l|l|}
\hline Development of Power Industry & \multicolumn{1}{|c|}{ Traditional Contents } & New or Added Contents \\
\hline Collectivization operation & Power enterprise management & Power group management \\
\hline Intensive development & $\begin{array}{l}\text { Human, finance, materials } \\
\text { management in power } \\
\text { enterprise }\end{array}$ & $\begin{array}{l}\text { Intensive management in } \\
\text { power enterprise }\end{array}$ \\
\hline Big sales, big service & $\begin{array}{l}\text { Power market } \\
\text { Financial management }\end{array}$ & $\begin{array}{l}\text { Power sales in rural } \\
\text { Rural power finance }\end{array}$ \\
\hline Big program, big overhaul & Power market & $\begin{array}{l}\text { Sales and service of power } \\
\text { enterprise }\end{array}$ \\
\hline $\begin{array}{l}\text { Big users direct purchase of } \\
\text { electricity }\end{array}$ & $\begin{array}{l}\text { Pecision-making of power } \\
\text { company } \\
\text { power industry }\end{array}$ \\
\hline
\end{tabular}

Teaching method. Power enterprise management involves all aspects of power enterprise's operation. The course has many basic theories, such as concepts, principles, methods of management, and so on. Thus, many teachers take method of "force-feeding". Teachers' exposition is the main or all action of the lessons. The class becomes more boring and students lose interest in this course. Therefore, teachers should take more other methods when teaching power enterprise management and make more design for their lessons.

\section{Conclusion}

Power enterprise management is a subject that integrates the basic theories of enterprise management into power enterprises. To arrange this course in electrical engineering academy and economics and management institute is good for students of the two academies to find job in power industry. On the basis of extensive investigation, this paper do some research on teaching power enterprise management considering the characteristics of the subject and the practical needs of the two academies. Combining with the recent development of power industry the paper comes to some conclusions.

First, it is better to set power enterprise management as a compulsory course and increase its lessons. Second, the textbook should be suitable for students and different chapters should be arranged different lessons for different academies. Third, teaching contents should be changed and renewed according to the hotspots of power industry. Forth, you'd better use all kinds of teaching methods and design your lessons elaborately. Last, universities and power enterprises promote cooperative teaching to satisfy the need of all parties.

In a word, it benefits all parties of students, universities, enterprises and society to do some corresponding teaching reform on power enterprise management. The next step is to make detailed design on teaching system and knowledge materials of this subject. Thus, power enterprise management will be an excellent course that satisfies the combination of engineering and 
management.

\section{References}

[1] Calderhead J. International experiences of teaching reform[J]. Handbook of research on teaching, 2001, 11(7): 777-802.

[2] Hammer M, Champy J. Reengineering the corporation: A manifesto for business revolution[J]. Business horizons, 1993, 36(5): 90-91.

[3] Yantao Wang. Teaching reform of the power enterprise management course based on combination of engineering and management[J]. Xueyuan, 2013, (19): 56-57.

[4] Scholtes P R. The leader's handbook: Making things happen, getting things done[M]. New York: McGraw-Hill, 1998: 13-24.

[5] Nikulina I E, Khomenko I V. Cognitive Management: Theory and Practice in the Organization[J]. Procedia-Social and Behavioral Sciences, 2015, 166: 441-445.

[6] Jiang X, Shui Y. Reform in Experiment Teaching and Cultivation of Students' Creative Ability [J]. Experiment Science \& Technology, 2006, 2: 28-29.

[7] Lei Su, Luo-xin Li, Min-fa Huang, etc. Research on course system and teaching methods of power enterprise management[J], Journal of electric power vocational and technical college in Wuhan, 2011, (1), 38-42.

[8] Jing-wen Li. Research on course construction system and design of electrical education and training[J], China power education, 2011, (18), 22-23.

[9] Yantao Wang. Thinking of the power enterprise management course construction[J]. Course Education Research, 2013, (29), 79-80.

[10] $\mathrm{Xu} \mathrm{S}$, Chen $\mathrm{W}$. The reform of electricity power sector in the PR of China[J]. Energy Policy, 2006, 34(16): 2455-2465.

[11] Yingjie Hao, Zhiguo Shui, Weiyu Guo. Present status of electric education in electricityrelated colleges[J], Journal of Technology College Education, 2007, 26(6), 60-62. 